\title{
Baseline seabed habitat and biotope mapping for a proposed marine reserve
}

Sonny TM Lee, Michelle Kelly, Tim J Langlois, Mark J Costello

Seabed mapping can quantify the extent of benthic habitats that comprise marine ecosystems, and assess the impact of fisheries on an ecosystem. In this study, the distribution of seabed habitats in a proposed no-take Marine Reserve along the northeast coast of Great Barrier Island, New Zealand, was mapped using underwater video combined with bathymetry and substratum data. As a result of the boundary extending to the 12 nautical mile Territorial Limit, it would have been the largest coastal Marine Reserve in the country. Recreational and commercial fisheries occur in the region and would be expected to affect species' abundance. The seabed of the study area and adjacent coastal waters has been trawled up to five times per year. Benthic communities were grouped by multivariate cluster analysis into four biotope classes; namely (1) shallow water macroalgae Ecklonia sp. and Ulva sp. on rocky substrata (Eck.Ulv); and deeper (2) diverse epifauna of sponges and bryozoans on rocky substrata (Pon.Bry), (3) brittle star Amphiura sp. and sea anemone Edwardsia sp. on muddy sand (Amph.Edw), and (4) hydroids on mud (Hyd). In biotopes Pon.Bry, Amph.Edw and Hyd, there where boulders and rocks were present, and diverse sponge, bryozoan and coral communities. Fifty species were recorded in the deep water survey including significant numbers of the shallow-water hexactinellid glass sponges Symplectella rowi Dendy, 1924 and Rossella ijimai Dendy, 1924, the giant pipe demosponge Isodictya cavicornuta Dendy, 1924, black corals, and locally endemic gorgonians. The habitats identified in the waters to the northeast of Great Barrier Island are likely to be representative of similar depth ranges in northeast New Zealand. This study provides a baseline of the benthic habitats so that should the area become a Marine Reserve, any habitat change might be related to protection from fishing activities and impacts, such as recovery of epifauna following cessation of trawling. The habitat map may also be used to stratify future sampling that would aim to collect and identify epifauna and infauna for identification, and thus better describe the biodiversity of the area. 
1 Baseline seabed habitat and biotope mapping for a proposed marine reserve

2

3

4

5

6

7

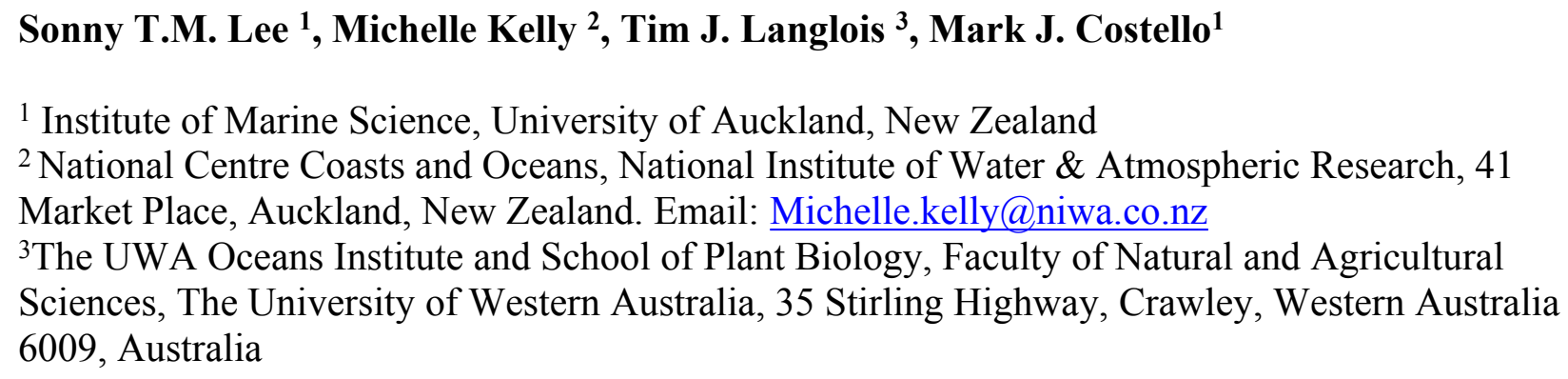


43

44

45

46

47

48

49

50

51

52

53

54

55

56

\begin{abstract}
Seabed mapping can quantify the extent of benthic habitats that comprise marine ecosystems, and assess the impact of fisheries on an ecosystem. In this study, the distribution of seabed habitats in a proposed no-take Marine Reserve along the northeast coast of Great Barrier Island, New Zealand, was mapped using underwater video combined with bathymetry and substratum data. As a result of the boundary extending to the 12 nautical mile Territorial Limit, it would have been the largest coastal Marine Reserve in the country. Recreational and commercial fisheries occur in the region and would be expected to affect species' abundance. The seabed of the study area and adjacent coastal waters has been trawled up to five times per year.

Benthic communities were grouped by multivariate cluster analysis into four biotope classes; namely (1) shallow water macroalgae Ecklonia sp. and Ulva sp. on rocky substrata (Eck.Ulv); and deeper (2) diverse epifauna of sponges and bryozoans on rocky substrata (Pon.Bry), (3) brittle star Amphiura sp. and sea anemone Edwardsia sp. on muddy sand (Amph.Edw), and (4) hydroids on mud (Hyd). In biotopes Pon.Bry, Amph.Edw and Hyd, there where boulders and rocks were present, and diverse sponge, bryozoan and coral communities. Fifty species were recorded in the deep water survey including significant numbers of the shallow-water hexactinellid glass sponges Symplectella rowi Dendy, 1924 and Rossella ijimai Dendy, 1924, the giant pipe demosponge Isodictya cavicornuta Dendy, 1924, black corals, and locally endemic gorgonians.

The habitats identified in the waters to the northeast of Great Barrier Island are likely to be representative of similar depth ranges in northeast New Zealand. This study provides a baseline of the benthic habitats so that should the area become a Marine Reserve, any habitat change might be related to protection from fishing activities and impacts, such as recovery of epifauna following cessation of trawling. The habitat map may also be used to stratify future sampling that would aim to collect and identify epifauna and infauna for identification, and thus better describe the biodiversity of the area.
\end{abstract}




\section{INTRODUCTION}

Understanding the spatial distribution of habitats is fundamental to establishing conservation areas and environmental impact assessment, and provides a baseline against which future change in biodiversity can be recognized (Neilsen and Costello, 1999; McMath et al., 2000; Costello, 2009; Leleu et al., 2012). Habitat maps provide the spatial structure of ecosystems that is fundamental to understanding biodiversity (Costello, 2001, 2009). The milieu of habitats not only characterizes an ecosystem, but provides a surrogate for estimating biodiversity where species level surveys are unavailable (Ward et al., 1999; Costello et al., 2010a). Habitat maps have also been used to identify sites that incorporate the ecological processes that support biodiversity, including the presence of exploitable species, vulnerable life stages, and habitat inter-connectivity (Roberts et al., 2003). They also provide the context for biodiversity management which operates at a landscape (and seascape) level (Perrings et al., 1992; Lundblad et al., 2006; Smale et al., 2012; Rovere et al., 2013).

Seabed mapping has improved with technical advances. Habitat mapping studies have been carried out using airborne and satellite remote sensing (Green et al., 1998; Mumby et al., 1998; Malthus and Mumby, 2003; Purkis and Pasterkamp, 2004; Lundblad et al., 2006), singlebeam acoustic ground discrimination systems (Foster-Smith and Sotheran, 2003), side-scan sonar and multibeam acoustic (Brown et al., 2002; Kenny et al., 2003), autonomous underwater vehicle (Smale et al., 2012) and underwater digital video (Andrefouet et al., 2008). These techniques vary in cost, resolution capabilities, and the need for data processing and expertise (BuhlMortensen et al., 2015). However, aerial and satellite methods only detect very shallow habitats depending on water transparency, so acoustic and drop-down video are the most effective nondestructive methods for waters where scuba diving is not practical (Emblow et al., 1999; Sides et al., 1995). In the present study, we mapped seabed habitats using video and available data on bathymetry and substrata off the north-east coast of New Zealand.

Almost half of the described marine species around New Zealand are endemic (Gordon et al., 2010), the highest proportion for any country in the world (Costello et al., 2010b). The Department of Conservation has a directive to protect a full range of marine habitats and ecosystems that represent New Zealand's indigenous marine biodiversity (Anon, 2000). There are currently 38 Marine Reserves in New Zealand that fully protect biodiversity (i.e. completely no-take) and act as control sites for studying the effects of fisheries on adjacent areas (Ballantine, 2014; Costello, 2014). In 2004 Marine Reserve status was proposed for the northeast coast of Great Barrier Island (Director-General for Conservation, 2004), but the application was declined by the Minister of Fisheries in 2008. The purpose of this paper is to (1) integrate all previous information on seabed habitats for the entire proposed Great Barrier Island Marine Reserve, including the seashore to deep (>80 m) waters, and (2) to map these areas. The impetus of the present study was to provide a baseline to support research and management should the area become a Marine Reserve (Langlois et al., 2006a), and provides the first seabed biotope maps below $40 \mathrm{~m}$ depth in the region.

\section{STUDY AREA}

Great Barrier Island is New Zealand's fourth largest island and is the largest island off the coast of the North Island (Figure 1). The surrounding waters range from relatively shallow inshore waters to deeper waters, and include coastal temperate rocky reef and soft-sediment habitats. The East Auckland Current, which is part of the larger South Pacific water circulation, has a strong influence on the coastal ecology of the region and the northeast coast of Great Barrier Island. 
117 Previous studies around Great Barrier Island included surveys in the shallower regions, such as 118 on the sub-tidal geology (Moore \& Kenny, 1985). Scuba surveys in seven localities in

119 Rangiwhakaea Bay found 63 species of fish, and reported that the dominant habitats were rocky 120 reef with encrusting, turfing, and larger seaweeds including Ecklonia radiata (kelp) and abundant in the area than on the mainland (Creese and McDowall 2001). Seaweed communities consisted of three zones, namely shallow mixed weed, encrusting and turfing algae, and kelp; and over 66 species of algae have been reported (Francis \& Grace, 1986). Five benthic communities on gravel to muddy-sand sediments from 35 dredge samples were mapped in the northeast corner of the island to approximately $60 \mathrm{~m}$ depth (Hayward et al., 1986). Morrison et al. (2001) carried out an acoustic survey of the seafloor habitats to the northeast of Great Barrier Island and provided broad-scale information about the habitats and communities. These studies were limited to shallow waters less than $80 \mathrm{~m}$, describing specific habitats such as soft corals, algal and fish distributions.

The area has less recreational fishing than areas closer to the mainland, but such pressure has not been quantified. However, from 2007-2010, the seabed area was trawled up to five times a year (Ministry for Primary Industries, 2012).

\section{METHODS}

The present study surveyed the area off the northeast coast of Great Barrier Island, between latitude $36.03^{\circ}$ and $36.45^{\circ}$ south and longitude $175.58^{\circ}$ and $176.28^{\circ}$ east, approximately $90 \mathrm{~km}$ northeast of Auckland, New Zealand (Figure 1). The area extends from Needles Point in the north to Korotit Bay in the south, and from mean high water spring to 12 nautical miles offshore. Sediment information from the nautical chart was digitized to map the substrata. The survey approach was to get an overview of the benthic biotopes for the area of the proposed reserve, and to increase sample density where there was greater physical habitat diversity (e.g. rocks) and decrease effort where previous data existed.

Three benthic surveys were undertaken around Great Barrier Island. The first survey, from 6-9 May 2002 and 17-20 December 2002, was at four rocky sites, using a video camera attached to a remotely operated vehicle (ROV). We updated species identifications from an earlier report of these samples by Sivaguru and Grace (2004). In October 2006, a combination of downward facing and horizontally facing remote underwater video (Langlois et al. 2010) was used to survey along the east coast of Great Barrier Island at 18 nearshore and 12 deepwater sites. Between April 2006 and September 2009, a Drop Down Video (DDV) (Figure 2) was used to survey 85 stations selected to fill gaps in geographic coverage of previous surveys, and validate depth and sediment information obtained from navigational charts. A total of 119 sites were surveyed in this study. Variations in bathymetry were initially identified using the depth sounder on the research vessel. Then the DDV was used to record the seabed relief, and the presence and relative abundance of the major habitat-forming flora and fauna. The DDV had a color video camera mounted at the base of a pyramidal stand (Figure 2). The video camera output a PAL composite video signal, approximately 450 horizontal lines, with 120 degree wide angle view. Sampling stations were illuminated by two light housings at both sides of the camera. Each light housing contained three high brightness, Luxeon type LED, with a total output of 1800 Lumen and 125 degree beam angle. The video camera and lights were attached to a waterproof, two-axis rotation device that could rotate the camera and lights 90 degrees vertically and 320 degree horizontally. Images were viewed in real-time aboard the ship so any malfunctions (e.g. leaks, 
163

164

camera fall) could be addressed. Weights were attached to the bottom of the stand to aid stability underwater. The camera and the battery pack were enclosed in a plexiglass container. Once the camera was dropped into the water, the survey began as soon as visibility was sufficient. The camera could rotate $360^{\circ}$ to view the habitat. When on the reef edge more than one habitat was recorded. By lifting the camera system off the seabed and drifting the boat, more samples were collected and time was saved by not needing to retrieve and redeploy the system. The video was left on the bottom for approximately 5 min at sample each location. Each sample comprised of the observations of habitat and taxa present at the sampling station. All video cameras used in this study were stationary and sampled a similar area size, to ensure that samples obtained were comparable.

All video footage was reviewed in the laboratory to identify the percent cover of the substrata and species. The number of specimens at each sampling station was counted. Analysis of species was on presence only as is typical in ecological studies looking across a wide variety of taxa where actual abundances and/or cover are not equivalent, and absences may not be true. The substrata were classified into five different categories - mud, rocks with sediments, sand, and a mixture of rocks and mud based on digitized images (Congalton \& Green, 1999). Rocky substrata were aggregations of loose carbonate or volcanic rock fragments. Individual rocks ranged in diameter from $0.25-3 \mathrm{~m}$, gravel $2-250 \mathrm{~mm}$, sand $0.1-2 \mathrm{~mm}$, and mud $<0.1 \mathrm{~mm}$. Substrate information was obtained from hydrographic and maritime chart (New Zealand Hydrographic Authority, Chart NZ 5222). Benthic invertebrates (Table 1) were identified directly from DDV video images; no specimens were examined. Species nomenclature follows the World Register of Marine Species (Costello et al. 2013, Boxshall et al., 2015, Van Soest et al., 2015).

The biotope map was digitized using ArcGIS 9.4, and Thiessen's polygon extension was used to distinguish depth-related patterns in substrata and the different biotope classes. A biotope was defined as a recurring assemblage of species associated with a particular physical habitat (Costello and Emblow 2005; Costello 2009). To identify potential species associations and biotopes, samples were (1) compared using Jaccard's coefficient of similarity on presenceonly species data, (2) clustered by species using the group-average method, and (3) statistically significant differences between groups tested using SIMPROF in the PRIMER-E version 6 software (Clarke and Gorley 2006). Jaccard's coefficient of similarity was used because it is the simplest similarity coefficient and robust enough to identify species associations.

\section{RESULTS}

The $30 \mathrm{~m}$ depth contour was less than $1 \mathrm{~km}$, and the $60 \mathrm{~m}$ contour about $3 \mathrm{~km}$, from the shoreline (Figure 1). Rocks and rubble dominated the shallow waters. With increasing depth, sand and then mud dominated the seabed, with occasional rocks. There were frequent rock outcrops with associated ledges and caverns. Beyond $90 \mathrm{~m}$ depth, most of the seabed was muddy with occasional patches of rocks and boulders (Figure 3). In most cases, boundaries between habitats were well defined using the combination of acoustic bathymetry and video surveys. Confident assessment of the current study using the Mapping European Seabed Habitats (MESH) project 'Remote Techniques Confidence Assessment' obtained an overall score of 69 (Table S1).

A total of 66 samples (out of 119 samples) were analysed further for clustering into various biotopes. The other 53 samples that were not analysed are mostly dominated by muddy seabed with no visible signs of epifauna. The 47 taxa identified were clustered into four groups (SIMPROF test, $\mathrm{p}=0.05$; Table 1, Figures 3,4 ). When combined with the substrata and depth, 
there were four distinct biotopes (Figure 5): (1) shallow water macro-algae, Ecklonia sp. and Ulva sp. on rocky substrata (Eck.Ulv); and deeper water (2) diverse epifauna of sponges and bryozoans on rocky substrata (Pon.Bry); (3) brittle star Amphiura sp. and sea anemone Edwardsia sp. on muddy sand (Amph.Edw); and (4) hydroids on mud (Hyd) (Figures 6, 7).

The rocky-seaweed biotope (Eck.Ulv) occurred in the shallow sub tidal, down to a maximum depth of $40 \mathrm{~m}$. Rubble and boulders dominated the sandy seabed. On sand, benthic species such as the sand dollar Fellaster sp. were common. Rubble and boulders were covered in kelp Ecklonia sp. and green algae Ulva sp., and other brown, red and green algae, and epifauna.

Beyond $30 \mathrm{~m}$ depth, in biotope Pon.Bry, there was a high diversity of epifauna, dominated by sponges and accompanied by gorgonian, corals and bryozoans (Table 1) where there were boulders and hard substrata for attachment. A total of 25 sponge species were tentatively identified from the video clips (Table 1). The number of sponge species identified at each site varied from between six and nine species, and many of the sponge specimens were quite large (Figure 8). Many more sponge species were seen in the video but were unable to be identified reliably. We identified 25 sponge species with relatively consistent and distinctive morphologies from video clips despite their reduced quality compared to still images. However, sponges with the same general morphology and colouration are not always the same species. For example, there were numerous bowl and fan-shaped haplosclerid species identified in the videos, which may be any one of at least four species: Haliclona (Gellius) petrocalyx (Dendy, 1924), Petrosia coralloides Dendy, 1924, Petrosia hebes Lendenfeld, 1888, and Calyx imperialis (Dendy, 1924). The latter three species are very difficult to accurately separate in the field, and even more difficult in images as the morphology of each species is highly variable and interchangeable between species. On the other hand, for species with distinctive morphologies such as Calyx imperialis (Dendy, 1924), which has one or two thin concentrically ridged and veined fans, identification is much easier and more certain if the image is clear. The same can be said for the thick-walled cups and bowls which were identified as species of Stelletta, Ancorina and Geodia spp. Thus, the identifications in Table 1 reflect the current state of our knowledge of species identity in the field from images. at least three black coral species were recorded from the video clips. Dead sections of tree branches that had fallen into the sea were covered in pink jewel anemones Corynactis sp. Brittle stars Astrobrachion constrictum were commonly seen on the living sections of coral. Large gorgonian Keratoisis sp. colonies were also present at some sites.

The muddy sand (biotope Amph.Edw), dominated by the brittle star Amphiura sp., and sea anemone Edwardsia sp., occurred between $30 \mathrm{~m}$ to $100 \mathrm{~m}$ depth (Figure 6). With more hard substrata the previously mentioned diverse epifauna biotope occurred. Thus the distribution of the biotopes depended on depth and substratum (Figure 6).

Where mud dominated the seabed (biotope Hyd), especially at deeper than $90 \mathrm{~m}$, there were no identifiable epifaunal assemblages, except for occasional hydroids (Figure 6). However, diverse epifauna biotope could be found when there are occasional rocks in this habitat.

\section{DISCUSSION}

The most diverse epifauna were associated with inshore and rocky reef habitats, and some of the area surveyed was deep muddy seabed with no visible epifauna. The substratum and depth formed the primary physical environment of the biotopes (Figure 6). The results agreed with and extended previous surveys, indicating that rocky substrata in shallow waters ( $\leq 40$ depth) were covered by macro-algae, Ecklonia sp. and Ulva sp. (Francis and Grace, 1986; Roberts et al., 
1986; Irving \& Jeffs, 1992; Kelly and Haggit, 2002). Most of the deep-water sites surveyed in this study were characterized by muddy sediment. Where boulders rose above the muddy seabed, there was a rich diversity of filter feeders and passive suspension feeders such as hydroids, ophiuroid brittle-star Amphiura sp., and anemone Edwardsia sp.

We recorded 47 invertebrate species, including sponges, gorgonians, black corals and anemones; and deep reef patches that were rich in epifaunal taxa. The two species of scleractinian corals recorded were previously reported on rocky and sediment habitats around Rakitu Island (Figure 1) below 25 m depth (Brooks 1982). In addition, Brook (1982) reported the scleractinians Culicia rubeola (Quoy \& Gaimard, 1833) and Sphenotrochus ralphae Squires, 1964. The former is $6 \mathrm{~mm}$ in diameter and encrusts rock crevices in $<25 \mathrm{~m}$ depth and latter is $c a$ $10 \mathrm{~mm}$ and occurred deeper than $25 \mathrm{~m}$ attached to shell on sediments. Neither species would be likely to have been observed by our sampling methods.

\section{Sponges}

Sponges dominated the invertebrate fauna of the deeper water sites confirming the results of a benthic sled survey in the deep waters off Great Barrier Island (Morrison et al., 2001).

One of the most important features of the sponge fauna was the presence of several species that are considered rare and restricted in distribution. Abundant specimens of the endemic glass sponge species Symplectella rowi were recorded, this being the first survey to identify a discrete population of the species in Northland waters. A single large specimen of the glass sponge Rossella ijimai was also recorded; this discovery is of particular importance as prior to this survey the species had not been found anywhere in New Zealand waters subsequent to its first description in 1924 (Dendy, 1924; Kelly et al., 2009). These two species were unusual for glass sponges as the majority of species have typically been found in very deep waters on the continental shelf and abyssal plain. Both species have subsequently been found off North Taranaki Bight (Jones et al., 2013).

The presence of several specimens of the giant vase sponge Isodictya cavicornuta Dendy, 1924 is also of considerable significance as this species is rare and has not been collected or recorded since the first description. This distinctive species is known elsewhere only from the Poor Knights where it was last photographed in the 1960s by Roger Grace.

A further feature of the sponge fauna was the presence of numerous large, solid cupshaped sponges, notably Geodia rex Dendy, 1924, Stelletta crater Dendy, 1924, S. maori Dendy, 1924, Petrosia hebes Lendenfeld, 1888, Calyx imperialis (Dendy, 1924), Petrosia coralloides Dendy, 1924, and Haliclona (Gellius) petrocalyx (Dendy, 1924).

The sponge fauna shared many species with the North Cape and Three Kings Islands deep-water regions (Dendy, 1924; Kelly et al., 2009), some $100 \mathrm{~km}$ further north of the present study area. The large size and abundance of these sponge specimens indicated that some of the community in the deep-reef sites has been relatively undisturbed from trawling and dredging (Tuck et al., 2007; Rooper et al. 2011). However, the Ministry for Primary Industries data (2012) indicated, that the seabed area was trawled up to five times a year between 2007 and 2010, and is still ongoing. It is possible that the absence of visible epifauna in $10 \%$ of the area is due to bottom trawling. Other fisheries in the area include angling, spearfishing, scuba diving and potting for crayfish, long-lining and purse seining (Director-General for Conservation 2004).

\section{Importance of habitat mapping}


300

301

302

303

304

305

306

307

308

309

310

311

312

313

314

315

316

317

318

319

320

321

322

323

324

325

326

327

328

329

330

331

332

333

334

335

336

337

338

339

340

341

342

343

344

345

Benthic ecosystem changes are best quantified with maps of the distribution of biotopes, both to enable detection of natural (including climatic) changes and comparisons between notake marine reserves and near-by areas that provide understanding of the impacts of human activities. Mapping habitats and biotopes thus aids in the selection of areas as part of a Marine Reserve network (Ward et al., 1999; Thrush et al., 2001; Parnell et al., 2006; Harborne et al., 2008b; Dalleau et al., 2010; Bianchi et al., 2012; Rovere et al., 2013), and quantifying fish habitat availability (Ortiz and Tissot, 2008, McLaren et al., 2015). The present study quantified the distribution of biotopes for future comparison on how fishing pressure may modify the Great Barrier Island marine ecosystem. Furthermore, the current study provided a baseline to access the recovery of biodiversity should the sampling area around Great Barrier Island be proposed as a Marine Reserve again.

Although the main purpose of the current study was to investigate the benthic ecosystem in the proposed marine reserve, it would also benefit conservation of fisheries outside the MPA. In a study done by Langlois and Anderson (2006) using similar underwater camera surveys, there was a total of 32 important target and iconic fish species in deepwater and nearshore waters around Great Barrier Island. Some of the most common demersal target species included snapper Pagrus auratus and tarakihi Nemadactylus macropterus. Although there was no evidence that there was any significant difference in the fish assemblage between the proposed marine reserve and comparable nearby areas, the authors predicted that closure to fishing will result in significant increases in fish densities both in the reserves and surrounding waters (Langlois and Anderson, 2006) as has been repeatedly found for reserves around the world (Costello 2014). Snapper $P$. auratus predation has major effects on rocky reef habitat structure in coastal marine reserves in northeastern New Zealand, through trophic cascades involving sea urchins and seaweeds (Babcock et al., 1999; Shears and Babcock 2003b), and soft-sediment communities (Langlois et al., 2005; 2006). Therefore, changes in the fisheries around the proposed marine reserve will likely have an impact on the benthic ecosystem and habitat (Langlois et al., 2005; 2012; Leleu et al. 2012).

In this study, the integration of existing bathymetric and sediment data provided a practical basis for stratifying the sampling using drop-down video. The video adequately identified the physical habitats at all locations and the dominant epifauna. However, in-situ sampling would be necessary to collect invertebrate specimens for species-level identification (Langlois et al., 2006b). This is especially the case for infauna in muddy sediments where no epifauna were visible. The present map provides a basis to design a sampling program for collecting invertebrate species to characterize the communities of the study area. This would be desirable if it is again proposed as a Marine Reserve because this information is needed to know what species the reserve would protect, and how representative it would be of the biodiversity of other areas in the region. In addition, this study provided the deepest maps of marine biotopes in New Zealand to date, and discovered new locations of global significance for glass sponge species.

\section{ACKNOWLEDGMENTS}

We thank Candace Rose-Taylor, Brady Doak, Murray Birch, Agnes Le Port, Jo Evans for assistance in the field, Dr Euan Harvey and Dr Di McLean for lending BRUV equipment, and Dr Kala Sivaguru and Dr Roger Grace for helpful discussion. Murray Birch built the rotating video camera system. 
Andréfouët, S., Costello, M.J., Rast, M., Sathyendranath, S. (2008). Earth observations for marine and coastal biodiversity. Remote Sensing of Environment 112 (8), 3297-3299.

Anon. (2000).New Zealand' biodiversity strategy. 146pp. Department of Conservation and Ministry for the Environment, Wellington.

Appeltans, W., Bouchet, P., Boxshall, G.A., Fauchald, K., Gordon, D.P., Hoeksema, B.W., Poore, G.C.B., van Soest, R.W.M., Stöhr, S., Walter, T.C., Costello, M.J. (eds) (2013). World Register of Marine Species. www.marinespecies.org.

Babcock, R.C., Kelly, S., Shears, N.T., Walker, J.W., Willis, T.J. (1999). Largescale habitat change in a temperate marine reserve. Marine Ecology Progress Series 189: 125-134

Ballantine, W.J. (2014). Fifty years on: lessons from Marine Reserves in New Zealand and principles for a worldwide network. Biological Conservation 176, 297-307.

Bianchi, C.N, Parravicini, V, Montefalcone, M., Rovere, A., Morri, C. (2012). The challenge of managing marine biodiversity: a practical toolkit for a cartographic, territorial approach. Diversity 4: 419-452.

Boxshall, G.A.; Mees, J.; Costello, M.J.; Hernandez, F.; Gofas, S.; Hoeksema, B.W.; Klautau, M.; Kroh, A.; Paulay, G.; Poore, G.; Read, G.B.; Stöhr, S.; de Voogd, N.; De Broyer, C.; Horton, T.; Kennedy, M.; Decock, W.; Dekeyzer, S.; Trias Verbeeck, A.; Vandepitte, L.; Vanhoorne, B.; Adams, M. J., Adlard, R., Adriaens, P., Agatha, S., Ahn, K. J., Ahyong, S., Alvarez, B., Alvarez, F., Anderson, G., Angel, M., Artois, T., Bail, P., Bailly, N., Bamber, R., Barber, A., Bartsch, I., Bellan-Santini, D., Berta, A., Bieler, R., Bitner, M. A., BłażewiczPaszkowycz, M., Bock, P., Böttger-Schnack, R., Bouchet, P., Boury-Esnault, N., Boyko, C., Brandão, S. N., Bray, R., Bruce, N. L., Caballer, M., Cairns, S., Cárdenas, P., Carrera-Parra, L. F., Carstens, E., Catalano, S., Cedhagen, T., Chan, B. K., Chan, T. Y., Cheng, L., Churchill, M., Coleman, C. O., Collins, A. G., Crandall, K. A., Cribb, T., Dahdouh-Guebas, F., Daneliya, M., Dauvin, J. C., Davie, P., Dayrat, B., De Grave, S., d'Hondt, J. L., Díaz, M. C., Dijkstra, H., Dohrmann, M., Dolan, J., Doner, S., Eibye-Jacobsen, D., Eitel, M., Emig, C., Epler, J., Faber, M., Fauchald, K., Fautin, D., Feist, S., Fernández-Rodríguez, V., Fišer, C., Foster, W., Frank, J. H., Fransen, C., Fraussen, K., Furuya, H., Garcia-Alvarez, O., Gasca, R., Gaviria-Melo, S., Gerken, S., Gheerardyn, H., Gibson, D., Gil, J., Gittenberger, A., Glasby, C., Glover, A., González Solís, D., Gordon, D., Grabowski, M., Guerra-García, J. M. ., Guiry, M. D., Hajdu, E., Hallermann, J., Harasewych, J., Harris, L., Hayward, B., Hendrycks, E., Ho, J. s., Høeg, J., Holsinger, J., Hooper, J., Houart, R., Hughes, L., Hummon, W., Iseto, T., Ivanenko, S., Janussen, D., Jarms, G., Jazdzewski, K., Just, J., Kamaltynov, R. M., Kaminski, M., Kantor, Y., Karanovic, I., Kelly, M., Kim, Y. H., King, R., Kirk, P., Kolb, J., KrappSchickel, T., Kremenetskaia, A., Krijnen, C., Kristensen, R., Kronenberg, G., Krylova, E., LaFollette, P., Lambert, G., Lazarus, D., LeCroy, S., Lefkowitz, E. J., Lemaitre, R., Lester, B., Londoño Mesa, M. H., Lowry, J., Macpherson, E., Madin, L., Mah, C., Manconi, R., Mapstone, G., Marshall, B., Marshall, D. J., Meland, K., Merrin, K., Messing, C., Mills, C., Molodtsova, T., Monsecour, K., Mooi, R., Moreira da Rocha, R., Moretzsohn, F., Mortimer, J., Nealova, L., Neubauer, T. A., Neuhaus, B., Ng, P., Nielsen, C., Nishikawa, T., Norenburg, J., O'Hara, T., Oliverio, M., Opresko, D., Osawa, M., Parker, A., Patterson, D., Paxton, H., Peñas, A., Perrier, V., Perrin, W., Pilger, J. F., Pisera, A., Polhemus, D., Pugh, P., Reid, D. G., Reimer, J. D., Reuscher, M., Rius, M., Robin, A., Rolán, E., Rosenberg, G., Rützler, K., Rzhavsky, A., Saiz-Salinas, J., Salazar-Vallejo, S., Sames, B., Sartori, A. F., Satoh, A., 
Scarabino, V., Schatz, H., Schierwater, B., Schmidt-Rhaesa, A., Schneider, S., Schönberg, C., Schotte, M., Schuchert, P., Segers, H., Self-Sullivan, C., Senna, A. R., Serejo, C., Shamsi, S., Shenkar, N., Siegel, V., Sinniger, F., Sivell, D., Sket, B., Smit, H., Staples, D., Sterrer, W., Stienen, E., Suárez-Morales, E., Summers, M., Suttle, C., Swalla, B. J., Tabachnick, K. R., Taiti, S., Tang, D., Tasker, M., Taylor, J., Tëmkin, I., ten Hove, H., ter Poorten, J. J., Terryn, Y., Thomas, J., Thuesen, E. V., Thurston, M., Thuy, B., Timi, J. T., Timm, T., Todaro, A., Tucker, J., Turon, X., Tyler, S., Uetz, P., Vacelet, J., Vader, W., Väinölä, R., van der Meij, S. E., van Ofwegen, L., van Soest, R., Van Syoc, R., Vanaverbeke, J., Vervaet, F., von Cosel, R., Vonk, R., Vos, C., Walker-Smith, G., Walter, T. C., Watling, L., White, K., Whitmore, D., Williams, G., Wilson, G. D., Wyatt, N., Wylezich, C., Yasuhara, M., Zanol, J., Zeidler, W. (2015). World Register of Marine Species. Accessed 2015-01-12 from http://www.marinespecies.org at VLIZ.

Brook, F. J. (1982). The scleractinian coral fauna of Rakitu Island, North-Eastern New Zealand. TANE 28, 163-173.

Brown, C.J., Cooper, K.M., Meadows, W.J., Limpenny, D.S., Rees, H.L. (2002). Small-scale mapping of sea-bed assemblages in the eastern English Channel using sidescan sonar and remote sampling techniques. Estuarine, Coastal and Shelf Science 54: 263-278.

Buhl-Mortensen, L., Buhl-Mortensen, P., Dolan, M. F., Holte, B. (2015). The MAREANO programme-A full coverage mapping of the Norwegian off-shore benthic environment and fauna. Marine Biology Research, 11(1), 4-17.

Clarke, K. R., \& Gorley, R. N. (2006). PRIMER version 6: user manual/tutorial. PRIMER-E, Plymouth, UK, 192 pp.

Congalton, R., \& Green, K. (1999). Assessing the accuracy of remotely sensed data: principles and practices. Lewis Publishers, New York. 137 pp.

Costello, M.J. \& Emblow, C. (2005). A classification of inshore marine biotopes. In: Wilson J. G. (ed.), The intertidal ecosystem: the value of Ireland's shores. Royal Irish Academy, Dublin, 25-35.

Costello, M.J. (2001). To know, research, manage, and conserve marine biodiversity. Océanis 24 (4), 25-49.

Costello, M.J. (2009). Distinguishing marine habitat classification concepts for ecological data management. Marine Ecology Progress Series 397, 253-268

Costello M.J. (2014). Long live Marine Reserves: A review of experiences and benefits. Biological Conservation 176, 289-296.

Costello, M.J., Bouchet, P., Boxshall, G., Fauchald, K., Gordon, D.P., Hoeksema, B.W., Poore, G.C.B., van Soest, R.W.M., Stöhr, S., Walter, T.C., Vanhoorne, B., Decock, W., Appeltans, W. (2013). Global coordination and standardisation in marine biodiversity through the World Register of Marine Species (WoRMS) and related databases. PLoS ONE 8(1): e51629.

Costello, M.J., Cheung, A., De Hauwere, N. (2010a). Topography statistics for the surface and seabed area, volume, depth and slope, of the world's seas, oceans and countries.

Environmental Science and Technology 44, 8821-8828.

Costello, M.J., Coll, M., Danovaro, R., Halpin, P., Ojaveer, H., Miloslavich, P. (2010b). A census of marine biodiversity knowledge, resources, and future challenges. PLoS ONE 5(8), e12110. doi:10.1371/journal.pone.0012110

Creese, B. \& McDowall, B. (2001). Marine and freshwater life. In: Armitage D (ed.), Great Barrier Island, Canterbury University Press.

Dalleau, M., Andréfouët, S., Wabnitz, C.C., Payri, C., Wantiez, L., Pichon, M., Friedman, K., 
Vigliola, L., Benzoni, F. (2010). Use of habitats as surrogates of biodiversity for efficient coral reef conservation planning in Pacific ocean islands. Conservation Biology 24, 541-552. Dendy, A (1924). Porifera. Non-antarctic sponges. Natural History report. British Antarctic (Terra Nova) Expedition, 1910. Zoology 6 (3):269-392.

Emblow, C.S., Costello, M.J., Wyn, G. (1999). Methods for mapping seashore and seabed biotopes in Wales and Ireland - INTERREG SensMap project. In: Davies H. (ed.), Emergency response planning. Irish Sea Forum Seminar Report Series No. 18/19, 51-58. Foster-Smith R.L., Sotheran I. (2003). Mapping marine benthic biotopes using ground discrimination systems.International Journal of Remote Sensing 24: 2761-2784.

Francis, M. P. \& Grace, R. V. (1986). Marine algal survey of northeastern Great Barrier Island, New Zealand. Journal - Royal Society of New Zealand, 16(4), 335-346.

Gordon, D. P., Beaumont, J., MacDiarmid, A., Robertson, D. A., Ahyong, S. T. (2010). Marine biodiversity of Aotearoa New Zealand. PLoS ONE 5(8), e10905. doi:10.1371/journal.pone.0010905

Green, E. P., Mumby, P. J., Edwards, A. J., Clark, C. D., Ellis, A. C. (1998). The assessment of mangrove areas using high resolution multispectral airborne imagery. Journal of Coastal Research 14(2), 483-443.

Harborne, A.R., Mumby, P.J., Kappel, C.V., Dahlgren, C.P., Micheli, F., Holmes, K.E., Brumbaugh, D.R. (2008b). Tropical coastal habitats as surrogates of fish community structure, grazing, and fisheries value. Ecological Applications 18, 1689-1701.

Hayward, B.W., Grace, R.V., Francis, M.P., Roberts, L. I. N., Ward, C. (1986). Sediments and benthos of northeastern Great Barrier Island, New Zealand. Journal - Royal Society of New Zealand, 16(4), 347-355.

Irving, P. J. \& Jeffs, A. G.(1992). The North-eastern coast of Great Barrier Island. A report on surveys of the coastal environment and a review of existing information. Technical Report Series.(No.5), Department of Conservation, Auckland Conservancy, New Zealand.

Jones, E.G., Morrison, M.A., Davey, N., Mills, S., Pallentin, A., George, S., Kelly, M., Shankar, U. (2013). Biogenic habitats on New Zealand's continental shelf. Part 2: National field survey and analysis. New Zealand Aquatic Environment and Biodiversity Report. Report prepared for the Ministry for Primary Industries.

Kelly, M., Edwards, A.R., Wilkinson, M.R., Alvarez, B., Cook, S.D.C., Bergquist, P.R., Buckeridge, J.S., Campbell, H., Reiswig, H.M. \& Valentine, C. (2009) Phylum Porifera sponges. In: Gordon, D.P. (ed), The New Zealand Inventory of Biodiversity Volume 1. Kingdom Animalia: Radiata, Lophotrochozoa, and Deuterostomia. Canterbury University Press, Christchurch, 23-46.

Kelly, S. \& Haggitt, T. (2002). Benthic reef survey of Waikaro Point to Needles Point, Great Barrier Island. Report prepared for the Department of Conservation, $36 \mathrm{pp}$.

Kenny, A.J., Cato I., Desprez, M., Fader, G., Schuttenhelm, R.T.E., Side, J. (2003). An overview of seabed-mapping technologies in the context of marine habitat classification. ICES Journal of Marine Science 60: 411-418.

Langlois, T.J., Anderson, M.J. , Babcock, R.C. (2005). Reef associated predators influence adjacent soft-sediment communities. Ecology 86:1508-1519.

Langlois, T. J., and Ballantine W.J. (2005). Marine ecological research in New Zealand: Developing predictive models through the study of no-take marine reserves. Conservation Biology 19:1763-1770.

Langlois, T.J., Anderson, M.J., Babcock, R.C., Kato, S. (2006). Marine reserves 
484

485

486

487

488

489

490

491

492

493

494

495

496

497

498

499

500

501

502

503

504

505

506

507

508

509

510

511

512

513

514

515

516

517

518

519

520

521

522

523

524

525

526

527

528

529

demonstrate trophic interactions across habitats. Oecologia 147:134-140.

Langlois, T.J. and M.J. Anderson (2006). Fish biodiversity survey at Great Barrier Island, Spring 2006: nearshore and deepwater communities. Auckland Conservancy. Department of Conservation. Auckland.

Langlois, T. J., M. J. Anderson, Babcock R. C. (2006a). Inconsistent effects of reefs on different size classes of macrofauna in adjacent sand habitats. Journal of Experimental Marine Biology and Ecology 334:269-282.

Langlois, T. J., M. J. Anderson, M. Brock, Murman G. (2006b). Importance of rock lobster sizestructure for trophic interactions: choice of soft-sediment bivalve prey. Marine Biology 149:447-454.

Langlois, T.J., Harvey, E.S., Fitzpatrick, B., Meeuwig, J.J., Shedrawi, G., Watson, D.L. (2010). Cost efficient sampling of fish assemblages: comparison of baited video stations and diver video transects. Aquatic Biology 9, 155-168.

Langlois, T. J., Harvey E. S., Meeuwig J. J. (2012). Strong direct and inconsistent indirect effects of fishing found using stereo-video: testing indicators from fisheries closures. Ecological Indicators 23:524-534.

Leleu, K., Remy-Zephir, B., Grace, R., Costello, M.J. (2012). Mapping habitat change after 30 years in a marine reserve shows how fishing can alter ecosystem structure. Biological Conservation 155, 193-201.

Lundblad, E.R., Wright, D.J., Miller, J., Larkin, E.M., Rinehart, R., Naar, D.F., Donahue, B.T., Anderson, S.M., Battista, T. (2006). A benthic terrain classification scheme for American Somoa. Marine Geodesy, 29:89-111.

Malthus, T.J. \& Mumby, P.J. (2003). Remote sensing of the coastal zone: an overview and priorities for future research. International Journal of Remote Sensing 24: 2805-2815.

McLaren, B. W., T. J. Langlois, E. S. Harvey, H. Shortland-Jones, Stevens R. (2015). A small no-take marine sanctuary provides consistent protection for small-bodied by-catch species, but not for large-bodied, high-risk species. Journal of Experimental Marine Biology and Ecology 471:153-163.

McMath, A., Cooke, A., Wyn, G., Jones, M., Robert, S., Emblow, C., Costello, M.J. 2000. Marine mapping techniques and their application to conservation management. Maritime Ireland/Wales INTERREG II Report, pp. 34-40.

Ministry for Primary Industries. (2012). Maps of Commercial Inshore Fishing Activity, Trawl Map retrieved from http://www.fish.govt.nz/ennz/Commercial/About+the+Fishing+ Industry /Maps + of + Commercial+Inshore+Fishing+Activity/default.htm on 15 January 2014.

Moore, P.R. \& Kenny, J. A. (1985). Geology of northeastern Great Barrier Island (Needles Point to Rangiwhakaea Bay) New Zealand. Journal - Royal Society of New Zealand 15(3), 235250.

Morley, M. S. \& Hayward, B. W. (2009). Marine Mollusca of Great Barrier Island, New Zealand. Records of the Auckland Museum, 15-51.

Morrison, M., Drury, J., Shankar, U. (2001). An acoustic survey of the seafloor habitats of Tiritiri Matangi Island and of the north-eastern side of Great Barrier Island. Consultancy report prepared by NIWA for the Department of Conservation.

Morrison, M., Drury, J., Al, E. (2001). An acoustic survey of the seafloor habitats of Tiritiri Matangi Island and of the northeastern side of Great Barrier Island. NIWA report.

Mumby, P.J., Green, E.P., Clark, C.D., Edwards, A. J. (1998). Digital analysis of multispectral airborne imagery of coral reefs. Coral Reefs, 17(1), 59-69. doi:10.1007/s003380050096 
530

531

532

533

534

535

536

537

538

539

540

541

542

543

544

545

546

547

548

549

550

551

552

553

554

555

556

557

558

559

560

561

562

563

564

565

566

567

568

569

570

571

572

573

574

575

Neilson, B. \& Costello, M.J. (1999). The relative lengths of seashore substrata around the coastline of Ireland as determined by digital methods in a Geographical Information System. Estuarine and Coastal Shelf Sciences 49, 501-508.

New Zealand Hydrographic Authority. Chart NZ 5222 Great Barrier Island (Aotea Island). Scale 1:50000. Auckland city, New Zealand, 2012.

Ortiz, D.M. \& Tissot, B.N. (2008). Ontogenic patterns of habitat use by reef-fish in a Marine Protected Area network: a multiscaled remote sensing and in situ approach. Marine Ecology Progress Series 365, 217-232.

Parnell, P.E., Dayton, P.K., Lennert-Cody, C., Rasmussen, L.L., Leichter, J.J. (2006). Marine reserve design: optimal size, habitats, species affinities, diversity and ocean microclimate. Ecological Applications 16, 945-962.

Perrings, C., Folke, C., Maler, K. G. (1992). The ecology and economics of biodiversity loss: the research agenda. Ambio 21(3), 201-211.

Purkis, S. J. \& Pasterkamp, R. (2004). Integrating in situ reef-top reflectance spectra with Landsat TM imagery to aid shallow-tropical benthic habitat mapping. Coral Reefs, 23(1), 520. doi:10.1007/s00338-003-0351-0

Remote Techniques Confidence Assessment. EMODnet Seabed Habitats, 2004. Web. 1 Oct. 2015. <http://www.emodnet-seabedhabitats.eu>.

Roberts, C.M., Andelman, S., Branch, G., Bustamante, R.H., Castilla, J.C., Dugan, J., Halpern, B.S., et al. (2003). Ecological criteria for evaluating candidate sites for marine reserves. Ecological Applications 13: 199 - 214.

Roberts, L.I.N., Ward, C., Francis, M.P., Hayward, B.W., Grace, R.V. (1986). Fishes of northeastern Great Barrier Island, New Zealand. Royal Society of New Zealand, 16(4), 357362.

Rooper, C.N., Wilkins, M.E., Rose, C.S., Coon, C. 2011. Modeling the impacts of bottom trawling and the subsequent recovery rates of sponges and corals in the Aleutian Islands, Alaska. Continental Shelf Research 31, 1827-1834.

Rossi, S. (2013). The destruction of the 'animal forests' in the oceans: towards an oversimplification of the benthic ecosystems. Ocean \& Coastal Management 84: 77-85.

Rovere, A., Ferraris, F., Parravicini, V., Navone, A., Morri, C., Bianchi, C. N. (2013). Characterization and evaluation of a marine protected area:'Tavolara-Punta Coda Cavallo'(Sardinia, NW Mediterranean). Journal of Maps 9(2), 279-288.

Shears, N.T. and Babcock, R.C. (2003b). Quantitative classification of New Zealand rocky coastal community types. Report to the Department of Conservation p.46.

Sides, E.M., Picton, B.E., Costello, M.J., Crean, E., Emblow, C.S., Gillmor, J., Kelly, K.S., Morrow, C.C. (1995). Identification and mapping of marine biotopes. In: Carroll M. and Dubsky K. (eds.), Coastal zone management: from needs to action, pp. 198-203.

Sivaguru, K. \& Grace, R. (2004). Habitat and species diversity of deep reefs and sediments at Great Barrier Island. Auckland Conservancy, Department of Conservation, Auckland, New Zealand.

Smale, D. A., Kendrick G. A., Harvey E. S., Langlois T. J., Hovey R. K., Van Niel K. P., Waddington K. I., Bellchambers L. M., Pember M. B., and Babcock R. C. (2012). Regionalscale benthic monitoring for ecosystem-based fisheries management (EBFM) using an autonomous underwater vehicle (AUV). ICES Journal of Marine Science: Journal du Conseil 69:1108-1118.

Thrush, S.F., Hewitt, J.E., Funnell, G.A., Cummings, V.J., Ellis, J., Schultz, D., Talley, D., 
Norkko, A. (2001). Fishing disturbance and marine biodiversity: the role of habitat structure in simple soft-sediment systems. Marine Ecology Progress Series 223, 277-286.

Tuck, I.D., Drury, J., Kelly, M., Geering, P. (2010). Designing a programme to monitor the recovery of the benthic community between North Cape and Cape Reinga. New Zealand Aquatic Environment and Biodiversity Report 78 p.

Van Soest, R.W.M; Boury-Esnault, N.; Hooper, J.N.A.; Rützler, K.; de Voogd, N.J.; Alvarez de Glasby, B.; Hajdu, E.; Pisera, A.B.; Manconi, R.; Schoenberg, C.; Janussen, D.; Tabachnick, K.R., Klautau, M.; Picton, B.; Kelly, M.; Vacelet, J.; Dohrmann, M.; Díaz, M.-C.; Cárdenas, P. (2015) World Porifera database. Accessed at http://www.marinespecies.org/porifera on 2015-01-14.

Ward, T. J., Vanderklift, M. A., Nicholls, A. O., Kenchington, R. A. (1999). Selecting marine reserves using habitats and species assemblages as surrogates for biological diversity. Ecological Applications, 9(2), 691-698. 


\section{Figure 1 (on next page)}

Study area.

Figure 1. The study area to the northeast of Great Barrier Island in New Zealand, southwest Pacific. The proposed Marine Reserve boundary is shown (solid line). Depth is shown from shallow (red) to deep (blue) with 30, 60, 90 and 120 m depth contours. Dots indicate locations of 119 sampling stations using ROV, BUV, and DDV underwater video. 


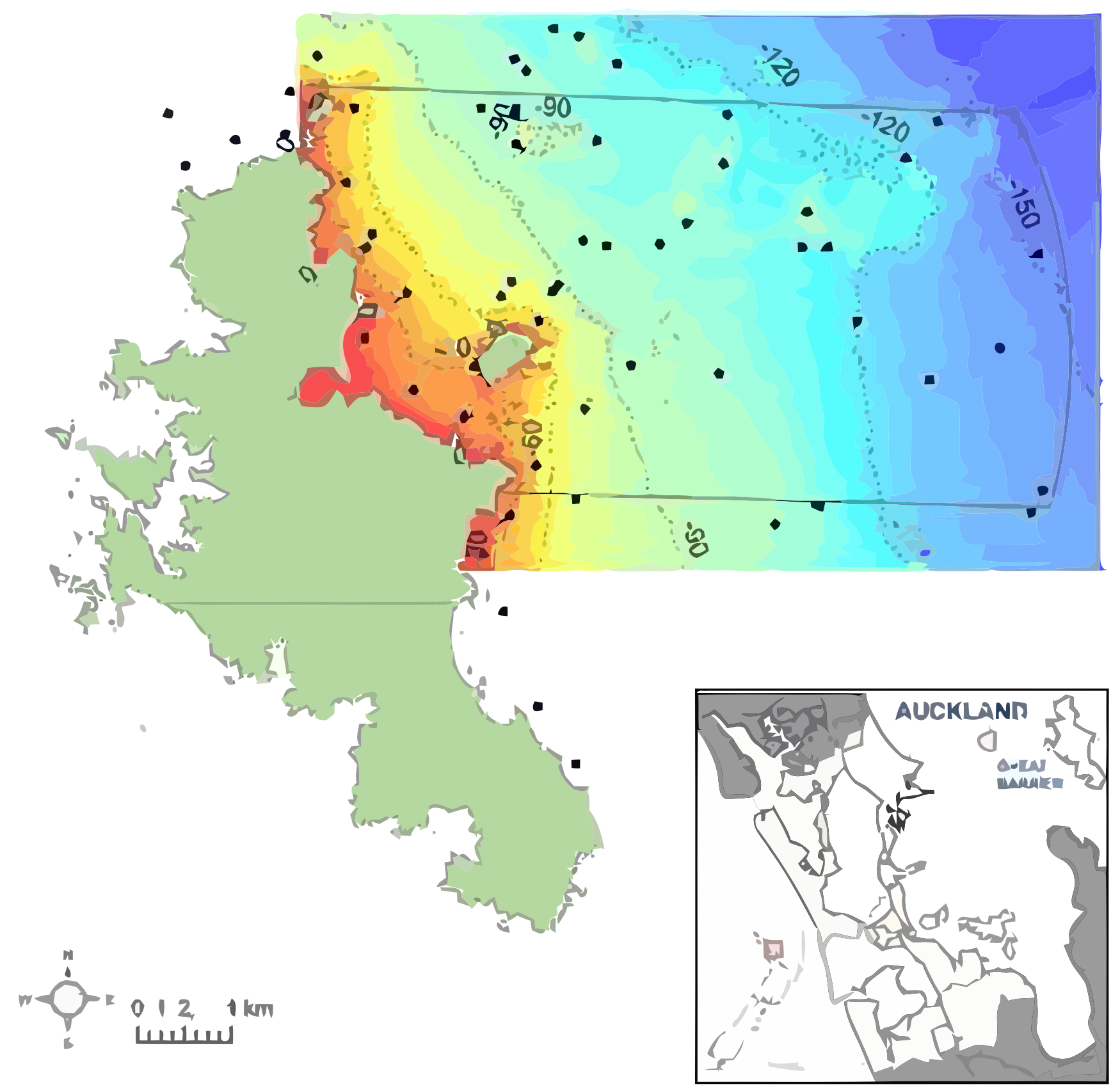


Figure 2 (on next page)

Drop-down video.

Figure 2. The drop-down video (DDV) system used at most 85 sampling stations in cruise 3 between April 2006 and September 2009. 


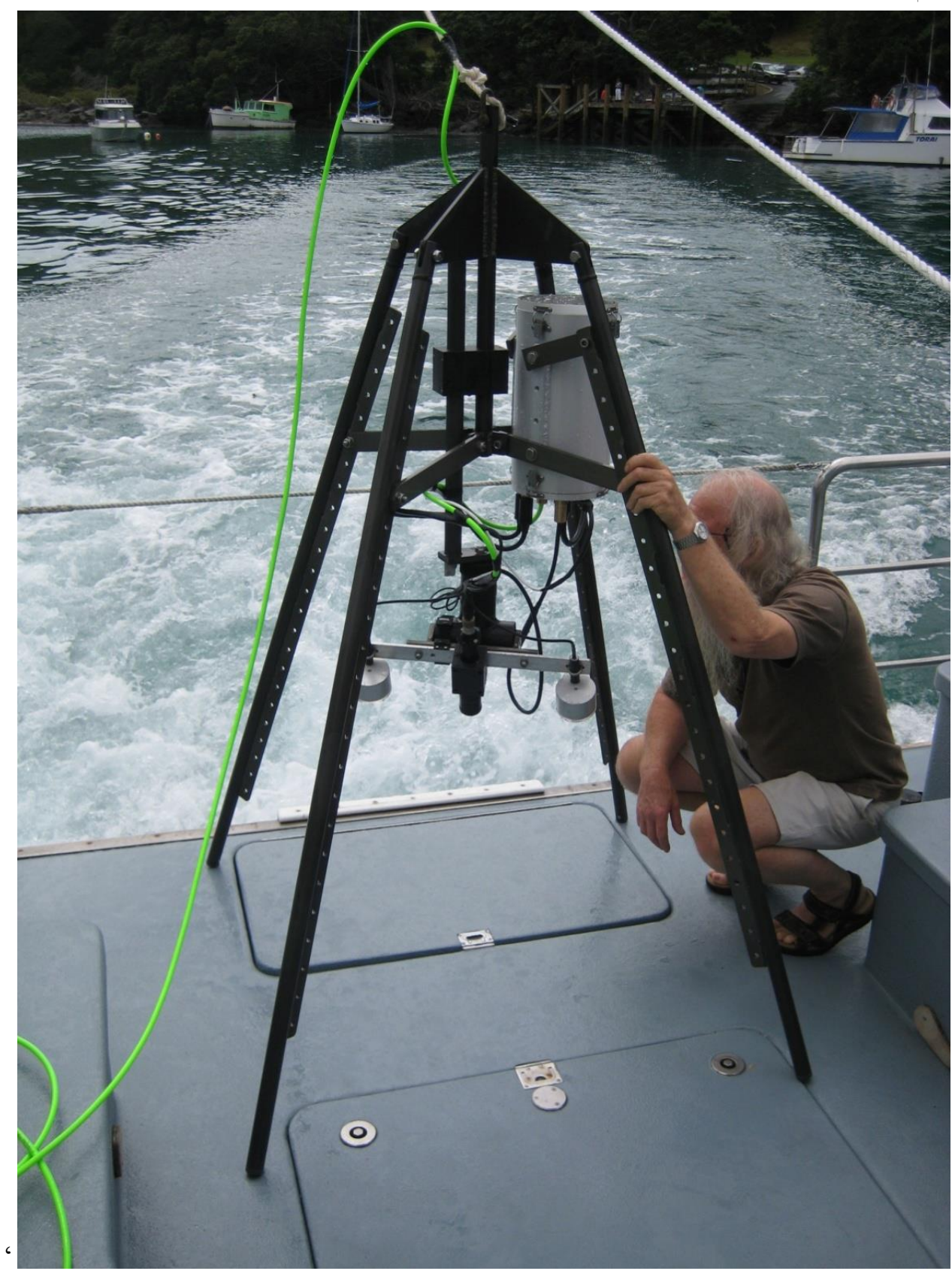


Figure 3 (on next page)

Cluster analysis.

Figure 3. Dendrogram of results of cluster analysis of samples based on taxa present. The substrata (symbols) and depth (numbers against samples) of each sample are indicated. The four clusters are from the top of the figure, deep-water samples dominated by (A) brittle star Amphiura sp. and sea anemone Edwardsia sp. (Amph.Edw), (B) diverse epifauna of sponges and bryozoans (Pon.Bry), (C) hydroids (Hyd), (D) algae (Eck.Ulv). 

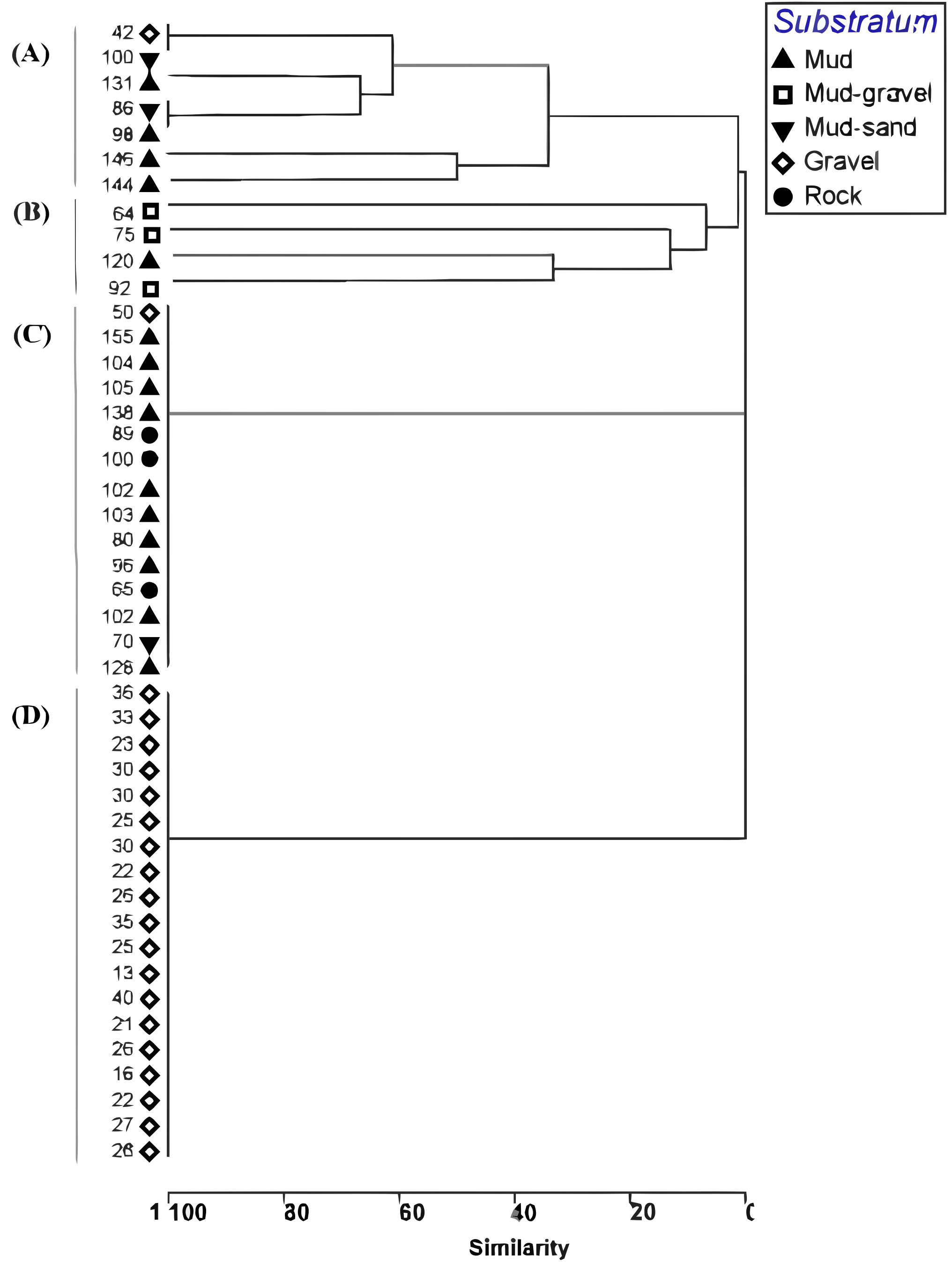


\section{Figure 4 (on next page)}

\section{Cluster analysis.}

Figure 4. Clustering of samples shows four species assemblages: (A) the sea anemone Edwardsia sp. and brittle star Amphiura sp. (Amph.Edw); (B) the diverse epifauna on hard substrata in deeper waters (Pon.Bry); (C) hydroids (Hyd); and (D) the kelp Ecklonia sp. and green algae Ulva sp. group (Eck.Ulv). 
(A)

Kionotrochus suteri

Caryophyllia quadragenaria

Conescharellina pala

Trachycladus stylifer

Callyspongia ramosa

Petrosia coralloides

Isodictya cavicomuta

Alcyonium sp.

Haliclona petrocalyx

Knightaster baken

Plumularia

Spongia gorgonocephalus

Stelletta crater

(B)

Stichopus mollis

Pleroma menoui

Symplectella rowi

Calyx imperialis

Corynactis sp.

Ophidiaster kemadecensis

Raspailia inequalis

Bunodactis Sp

Comanthus $s p$

Holothuria zelandica

Hymeniacidon spherodigitata

Polymastia crocea

Rossella ijimai

Stelletta maon

Ancorina stalagmoides

Asterodiscus truncates

Antipatharia sp. undet

Lophon laevistylus

Aciculites pulchra

Biemna nfescens

Monomyces rubrum

Phidoloporidae

eucettusa lancifer

Axinellidae or Raspaiiidae sp.

Keratoisis

Chondropsis kirkil

Geodia rex

(C)

Iophon laevistylus

Petrosia hebes

Hydrozoa

(D)

Phaeophyceae (Kelp)

Ulva

100

80

60

Similarity 
Figure $\mathbf{5}$ (on next page)

Cluster analysis.

Figure 5. An alternative presentation of the samples in Figure 3 using non-metric multidimensional scaling (MDS). Vectors show selected (to avoid cluttering plot) taxa indicating the species assemblages. Symbols indicate substrata as in Figure 3. The four biotopes are indicated by dotted circles: (A) brittle star Amphiura sp. and sea anemone Edwardsia sp. (Amph.Edw), (B) diverse epifauna of sponges and bryozoans (Pon.Bry), (C) hydroids (Hyd), (D) algae (Eck.Ulv). 
(C) 2D Stress: 0.01

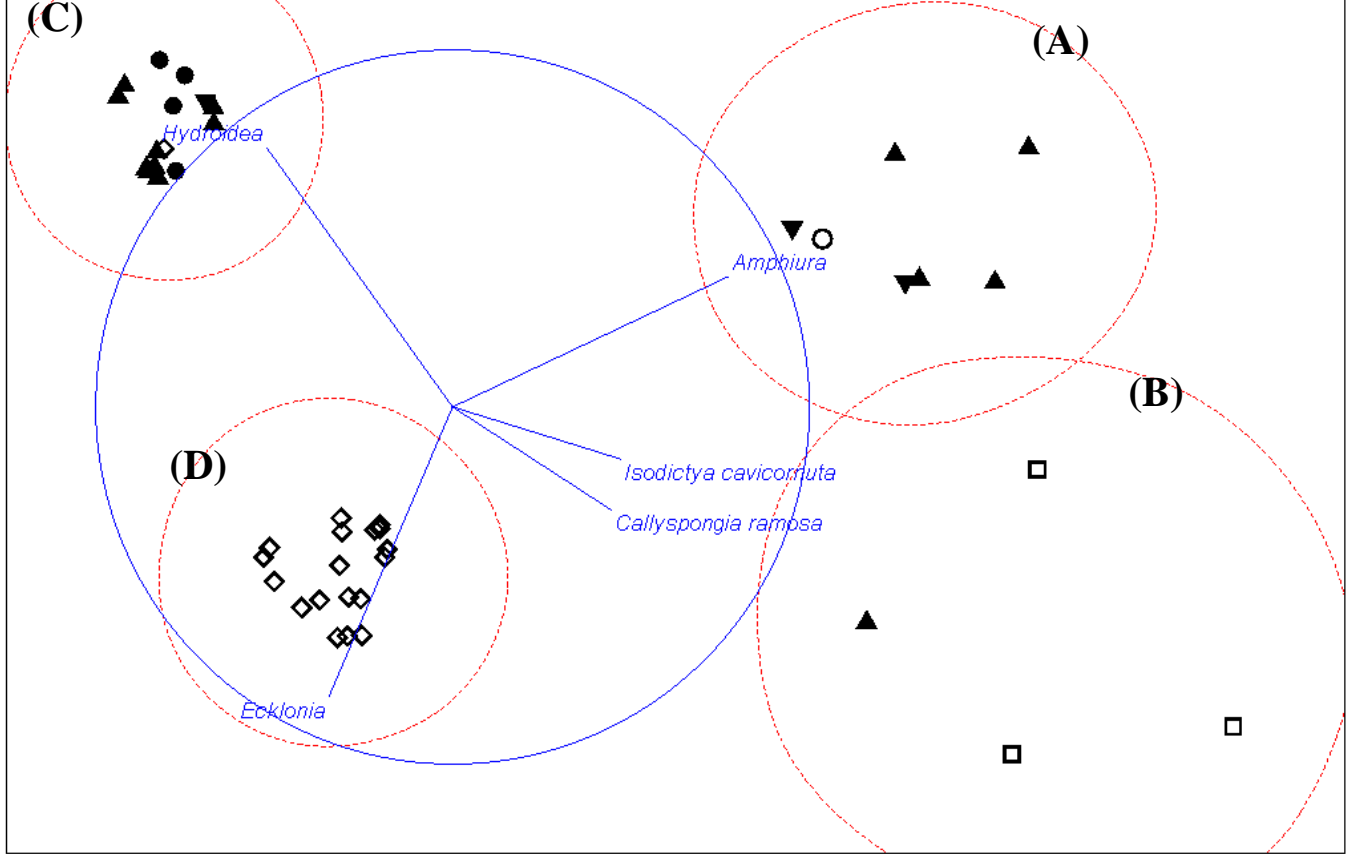




\section{Figure 6 (on next page)}

\section{Biotopes matrix.}

Figure 6. Map and matrix of the biotopes in the study area off Great Barrier Island, latitude $36.03^{\circ}$ and $36.45^{\circ}$ south and longitude $175.58^{\circ}$ and $176.28^{\circ}$ east (land is dark green). Depth contours are in metres. White areas on the map were muddy with no visible epifauna 


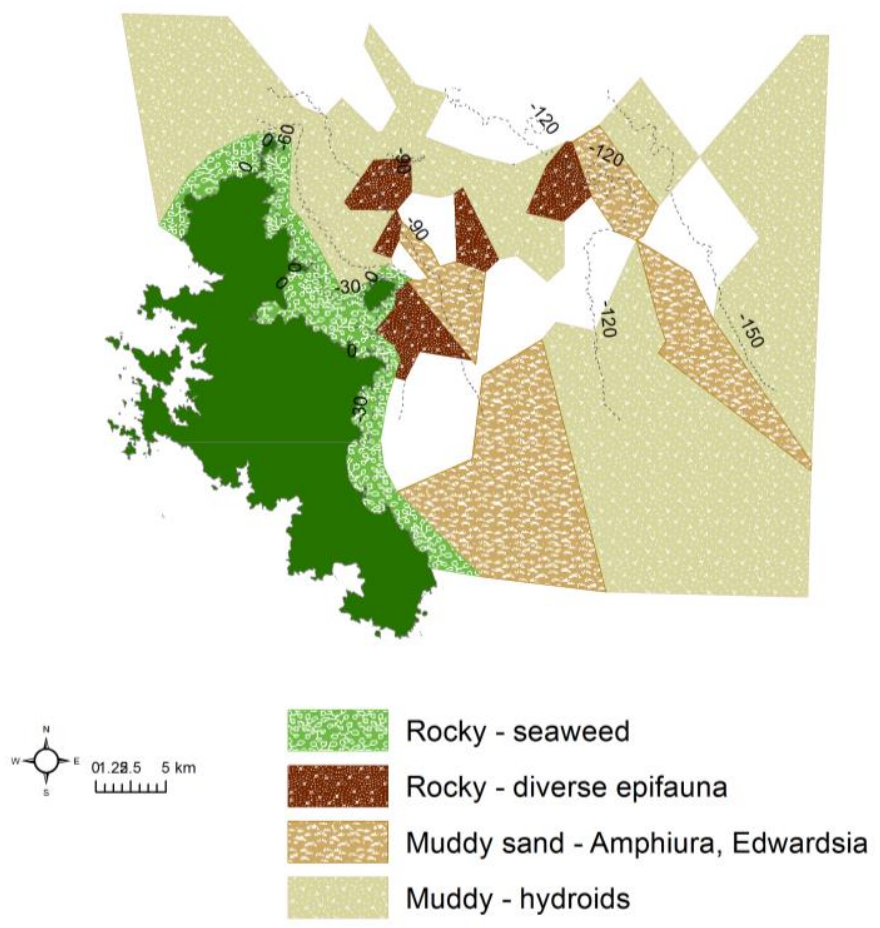

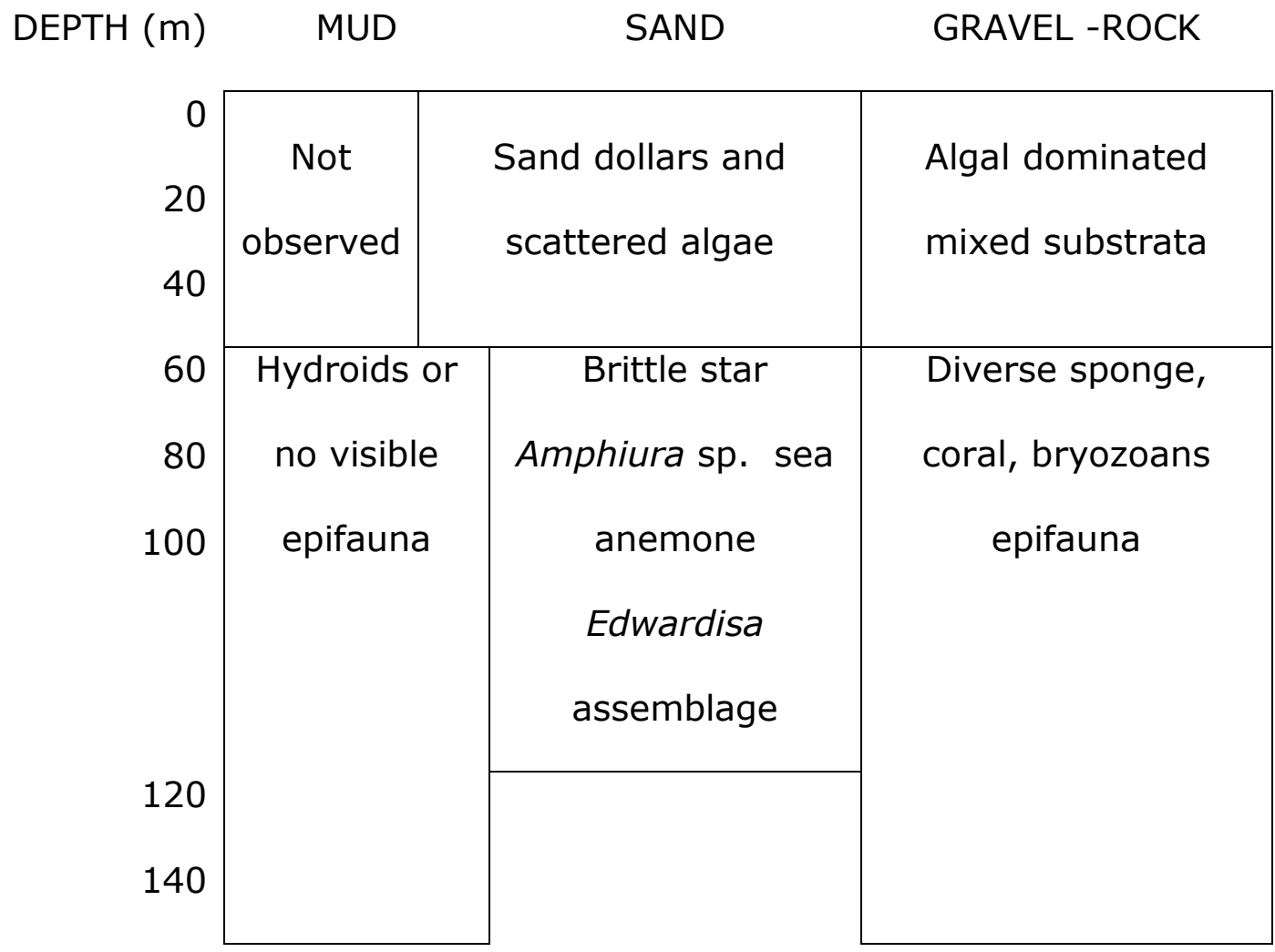


Figure 7 (on next page)

Biotopes.

Figure 7. Images of the biotopes found. (a) Shallow $(<20 \mathrm{~m})$ rocks covered with encrusting coralline algae, kelp, sponges, corals and bryozoans in biotope Eck.Ulv. (b) Deep (> $80 \mathrm{~m}$ ) mud with sponges and bryozoans growing on any hard substrata in Pon.Bry. (c) Brittle star Amphiura sp. and sea anemone Edwardsia sp. on muddy sand in Amph.Edw (d) Deep (> 90 $\mathrm{m})$ mud with hydroids and no identifiable epifauna in Hyd. 
(a)

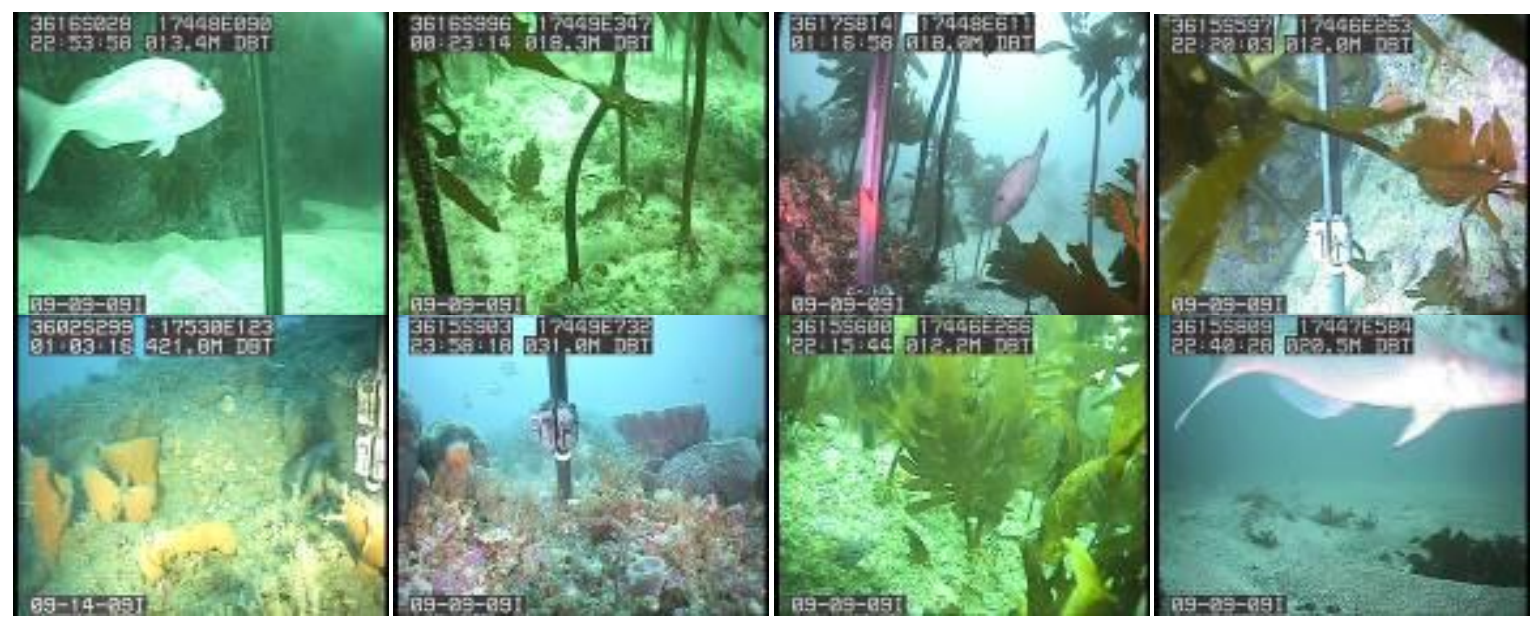

(b)

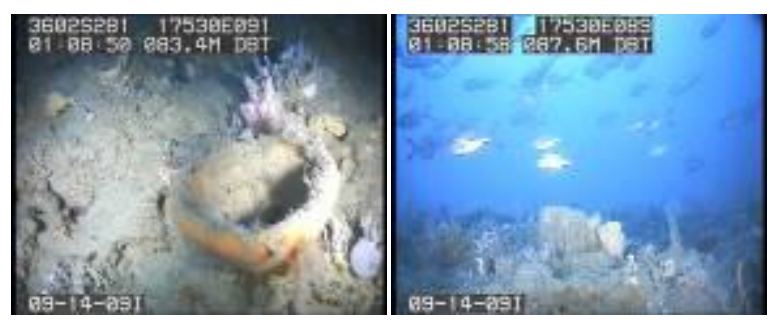

(c)

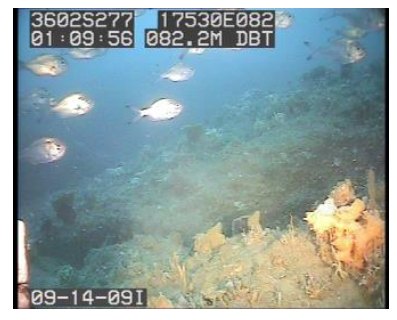

(d)

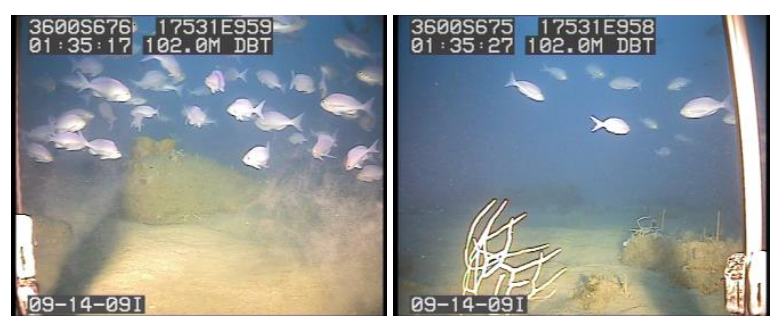




\section{Table $\mathbf{1}$ (on next page)}

Species recorded in study.

Table 1. Species recorded in the present study from images. Nomenclature follows Boxshall et al. (2015) and Van Soest et al. (2015). 


\begin{tabular}{llll}
\hline Class & Order & Family & Species \\
\hline
\end{tabular}

\section{Bryozoa}

Gymnolaemata

Gymnolaemata

Cheilostomatida

Cheilostomatida

\section{Chlorophyta}

Ulvophyceae

\section{Cnidaria}

Anthozoa

Anthozoa

Anthozoa

Anthozoa

Anthozoa

Anthozoa

Anthozoa

Anthozoa

Anthozoa

Anthozoa

Hydrozoa

\section{Echinodermata}

Asteroidea

Asteroidea

Asteroidea

Crinoidea

Holothuroidea

Ophiuroidea

\section{Ochrophyta}

Phaeophyceae

\section{Actiniaria}

Actiniaria

Alcyonacea

Alcyonacea

Antipatharia

Corallimorpharia

Hydroida

Scleractinia

Scleractinia

Scleractinia

Leptothecata
Conescharellinidae

Otionellidae
Conescharellina pala Gordon, 1989

Otionellina affinis (Cook \& Chimonides, 1984)

Ulvaceae

Ulva sp. indet Linnaeus, 1753

Actiniidae Bunodactis Verrill, 1899 sp. indet.

Edwardsiidae

Edwardsia Quatrefages, 1842 sp. indet.

Alcyonidae

Isididae

Alcyonium Linnaeus, 1758 sp. indet.

Keratoisis Wright, 1869 sp. indet.

Antipathidae

Corallimorphidae

Antipatharia Pallas, 1766 sp. indet

Hydrozoa

Corynactis Allman, 1846 sp. indet.

Caryophylliidae

indet. Owen, 1843

Flabellidae

Caryophyllia quadragenaria Lamarck, 1801

Monomyces rubrum (Quoy \& Gaimard, 1833)

Turbinoliidae

Kionotrochus suteri Dennant, 1906

Plumulariidae

Plumularia Lamarck, 1816 sp. indet.

Asterodiscididae

Ganeriidae

Ophidiasteridae

Comatulidae

Stichopodidae

Amphiuridae
Asterodiscides truncatus (Coleman, 1911)

Knightaster bakeri H.E.S. Clark, 1972

Ophidiaster kermadecensis Benham, 1911

Comanthus AH Clark, 1908 sp. indet.

Stichopus mollis (Hutton, 1872)

Amphiura Forbes, 1843 sp. indet.

Indet.

Indet. Kjellman, 1891

\section{Porifera}

Calcarea

Clathrinida

Leucaltidae

Leucettusa lancifer Dendy, 1924

Hexactinellida

Lyssacinosida

Hexactinellida

Lyssacinosida

Demospongiae

Rossellidae

Rossellidae

Ancorinidae
Rossella ijimai Dendy, 1924

Symplectella rowi Dendy, 1924

Ancorina stalagmoides Dendy, 1924 ? 


\begin{tabular}{|c|c|c|c|}
\hline Demospongiae & Astrophorida & Ancorinidae & Stelletta crater Dendy, 1924 \\
\hline Demospongiae & Astrophorida & Ancorinidae & Stelletta maori Dendy, 1924 \\
\hline Demospongiae & Astrophorida & Geodiidae & Geodia rex Dendy, 1924 (rare form) \\
\hline Demospongiae & Dictyoceratida & Spongiidae & Spongia gorgonocephalus Cook \& Bergquist, 2001 \\
\hline Demospongiae & Hadromerida & Polymastiidae & $\begin{array}{l}\text { Polymastia croceus } \\
\text { Kelly-Borges \& Bergquist, } 1997\end{array}$ \\
\hline Demospongiae & Hadromerida & Suberitidae & Homaxinella erecta (Brondsted, 1924)? \\
\hline Demospongiae & Hadromerida & Trachycladidae & Trachycladus stylifer Dendy, 1924 \\
\hline Demospongiae & Halichondrida & Halichondriidae & Hymeniacidon sphaerodigitata Bergquist, 1970 \\
\hline Demospongiae & Halichondrida & Halichondriidae & Axinellidae spp. indet. \\
\hline Demospongiae & Haplosclerida & Callyspongiidae & $\begin{array}{l}\text { Callyspongia ramosa } \\
\text { Duchassaing \& Michelotti, } 1864\end{array}$ \\
\hline Demospongiae & Haplosclerida & Chalinidae & Haliclona (Gellius) petrocalyx (Dendy, 1924) \\
\hline Demospongiae & Haplosclerida & Petrosiidae & Neopetrosia sp. indet. \\
\hline Demospongiae & Haplosclerida & Petrosiidae & Petrosia coralloides Dendy, 1924 \\
\hline Demospongiae & Haplosclerida & Petrosiidae & Petrosia hebes Lendenfeld, 1888 \\
\hline Demospongiae & Haplosclerida & Phloeodictyidae & Calyx imperialis (Dendy, 1924) \\
\hline Demospongiae & Lithistid Demospongiae & Pleromidae & Pleroma menoui Lévi \& Lévi, 1983 \\
\hline Demospongiae & Lithistid Demospongiae & Scleritodermidae & Aciculites pulchra Dendy, 1924 \\
\hline Demospongiae & Poecilosclerida & Acarnidae & Iophon laevistylus Dendy, 1924 \\
\hline Demospongiae & Poecilosclerida & Acarnidae & Iophon minor (Brondsted, 1924) \\
\hline Demospongiae & Poecilosclerida & Chondropsidae & Chondropsis kirkii (Bowerbank, 1841)? \\
\hline Demospongiae & Poecilosclerida & Isodictyidae & Isodictya cavicornuta Dendy, 1924 \\
\hline Demospongiae & Poecilosclerida & Raspailiidae & Raspailia inequalis Dendy, 1924 \\
\hline
\end{tabular}

